\title{
A Novel Technique for the Removal of Anteriorly Migrated Dexamethasone Intravitreal Implant
}

\author{
Andrew J McClellan and Thomas A Albini* \\ Department of Ophthalmology, University of Miami, USA
}

Submission: February 22, 2017; Published: March 02, 2017

*Corresponding author: Thomas A Albini, Bascom Palmer Eye Institute, University of Miami Miller School of Medicine, 900 NW 17 th Street, Miami, FL 33136, USA, Tel: 305-326-6000, Fax: 305-326-6417; Email: wsmiddy@med.miami.edu

\begin{abstract}
The migration of a dexamethasone intravitreal implant (Ozurdex) into the anterior chamber can cause corneal decompensation which may necessitate removal. The implant often fragments when forceps are used and standard vitrectomy instrumentation is suboptimal due to the small opening of the port relative to the size of the implant. We propose the use of a phacoemulsification hand piece for removal of the implant, which has a lumen large enough to assume the implant, infusion to maintain the depth of the anterior chamber, and the ability to emulsify the implant.

Keywords: Phacoemulsification; Dexamethasone; Implant; Migration
\end{abstract}

\section{Introduction}

The Dexamethazone intravitreal implant [1] has been approved by the United States Food and Drug Administration for the treatment of macular edema associated with retinal vein occlusion, noninfectious uveitis involving the posterior segment, and diabetic macular edema. The implant is contraindicated in patients whose posterior lens capsule is torn or ruptured because of the risk of migration into the anterior chamber. However, laser capsulotomy in pseudophakic patients is not a contraindication [1]. The migration of the implant into the anterior chamber, especially if soon after its implantation, can cause corneal decompensation which may necessitate its removal [2,3]. Reported techniques for removal include the use of a vitrector, forceps, viscoelastic, or a Sheets glide [4,5]. However, the implant often fragments when forceps are used and standard vitrectomy instrumentation is often ineffective due to the small opening of the port relative to the size of the implant [3]. Others have reported successful relocation of the implant into the posterior segment with mydriatics and head positioning, external digital force, or manipulation with a needle in the clinic [6-8]. Nevertheless, the implant may still migrate into the anterior chamber yet again [9].

\section{Technique}

The experimental surgical video provided demonstrates a beveled, clear corneal incision created with a 2.5 millimeter keratome blade in a porcine eye after inflation of the chamber with viscoelastic. A phacoemulsification hand piece (CENTURION@ Vision System, Alcon Laboratories, Inc. Fort Worth, TX) was then introduced into the anterior chamber and used on a high-vacuum setting to engage the implant on its long axis, allowing for efficient emulsification and aspiration.

\section{Discussion}

We propose the use of a phacoemulsification handpiece for removal of the implant, which has a lumen large enough to assume the implant, infusion to maintain the depth of the anterior chamber, and the ability to emulsify the implant. The diameter of the Ozurdex implant is 0.46 milimeters, while the diameter of the opening of many phacoemulsifcation probes is $0.5-0.9$ milimeters. This technique utilizes the procedures and instrumentation of cataract phacoemulsification that are familiar to all ophthalmologists.

\section{Declarations}

Presented at the Sociedad Panamericana de Enfermedades Inflamatorias Oculares, Las Vegas, NV, November 14, 2015.

\section{Competing Interests}

TA is a consultant for Allergan. AM has no relevant interests.

\section{Authors' contributions}

Conception of project and preparation of manuscript - AM and TA. 


\section{References}

1. (2014) OZURDEX® Full prescribing information. Allergan, Inc. Irvine, California, USA.

2. Pardo-Lopez D, Frances-Munoz E, Gallego-Pinazo R, Diaz-Llopis M (2012) Anterior chamber migration of dexametasone intravitrea implant (Ozurdex(R)). Graefe's archive for clinical and experimental ophthalmology = Albrecht von Graefes Archiv fur klinische und experimentelle Ophthalmologie. 250(11): 1703-1704.

3. Khurana RN, Appa SN, McCannel CA, Elman MJ, Wittenberg SE, et al. (2014) Dexamethasone implant anterior chamber migration: risk factors, complications, and management strategies. Ophthalmology 121(1): 67-71.

4. Stelton CR, Townsend J, Peterson LT, Khurana RN, Yeh S (2015) Surgica Management of Anterior Chamber Migration of a Dexamethasone

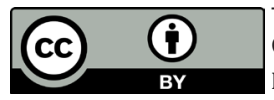

This work is licensed under Creative Commons Attribution 4.0 License

DOI: $10.19080 / J 0 J 0.2017 .02 .555578$
Intravitreal Implant. Ophthalmic Surg Lasers Imaging Retina 46(7): 756-759.

5. Pitcher JD (2014) A No-Touch Technique for Removal of a Dexamethasone Implant. ( $3^{\text {rd }}$ edn) Retina Today, USA, p. 36-38.

6. Kishore SA, Schaal S (2013) Management of anterior chamber dislocation of dexamethasone implant. Ocul Immunol Inflamm 21(1): 90-91.

7. Collet B (2013) Management of ozurdex in the anterior chamber. JAMA Ophthalmol 131(12): 1651-1652.

8. Vela JI, Crespi J, Andreu D (2012) Repositioning of dexamethasone intravitreal implant (Ozurdex) migrated into the anterior chamber. Int Ophthalmol 32(6): 583-584.

9. Bansal R, Bansal P, Kulkarni P, Gupta V, Sharma A, et al. (2011) Wandering Ozurdex® implant. J Ophthalmic Inflamm Infect 2(1): 1-5.

Your next submission with Juniper Publishers will reach you the below assets

- Quality Editorial service

- Swift Peer Review

- Reprints availability

- E-prints Service

- Manuscript Podcast for convenient understanding

- Global attainment for your research

- Manuscript accessibility in different formats ( Pdf, E-pub, Full Text, Audio)

- Unceasing customer service

Track the below URL for one-step submission https://juniperpublishers.com/online-submission.php 